\title{
The Definitive Eradication of Helicobacter pylori from the Colon
}

\author{
Abdullah M Nasrat ${ }^{1^{*}}$, Salwa AM Nasrat ${ }^{2}$, Randa M Nasrat ${ }^{3}$ and Mohammad M Nasrat ${ }^{3}$
}

${ }^{1}$ Department of Surgery, Balghsoon Clinic, Jeddah, KSA

${ }^{2}$ Department of Physical Therapy, Cardiac Surgery Academy, Cairo, Egypt

${ }^{3}$ Department of Internal Medicine, Helwan General Hospital, Helwan, Egypt

*Corresponding author: Abdullah M Nasrat, Department of Surgery, Balghsoon Clinic, Jeddah, PO Box 5261 KSA-21573, Tel: +966 (012) 667 3645; E-mail: abdullahalnasrat@hotmail.com

Rec date: July 01, 2015 Acc date: October 19, 2015 Pub date: October 23, 2015

Copyright: ( 2015 Nasrat AM, et al. This is an open-access article distributed under the terms of the Creative Commons Attribution License, which permits unrestricted use, distribution, and reproduction in any medium, provided the original author and source are credited.

\begin{abstract}
The study aimed at the assessment of Helicobacter pylori eradication from the colon by a natural measure.

H. pylori colonized the stomach since an immemorial time as if both the stomach wall and the bacterium used to live together in peace harmless to each other.

H. pylori could migrate or get forced to migrate to colon where it will continue to produce ammonia for a reason or no reason, unopposed or buffered by any acidity, leading to accumulation of ammonia in profuse toxic amounts that could lead adverse toxic effects in the body in predisposed disadvantaged population. $H$. pylori eradication from the colon in this situation should be therefore a necessary attempt.

22 middle-aged patients with recurrent colonic troubles were included in this study according to their clinical symptoms and laboratory testing. Patients who were found positive for $H$. pylori fecal antigen were given a potent natural purgative.

20 patients showed positive colonic $H$. pylori strains, 19 patients were turned negative after employment of the potent natural senna leaves purge.

The natural senna leaves purge is an effective potent and safe measure for eradication of colonic $H$. pylori strains.
\end{abstract}

Keywords: Helicobacter pylori; Colon

\section{Introduction}

Helicobacter pylori represents one of the most common and medically prominent challenges worldwide. About $50 \%$ of adults in the developed and $80-90 \%$ in the developing countries are estimated to be affected by $H$. pylori [1]. Infection with $H$. pylori is typically life-long unless treated. It has got a clear age-related prevalence [2]. In children, existence of $H$. pylori starts trans-familial during early childhood, and $H$. pylori strain is often identical with that of parents. Interestingly, children maintain the same strain genotype even after moving to a different environment [3].

H. pylori resides and colonizes under the layer of mucus overlying gastric mucosa; colonization rates increase with age that could reach $50 \%$ in an asymptomatic adult over 50 years of age. H. pylori is existing mainly in the stomach since an immemorial time but it can exist and reside in many other sites in the body such as dental plaques, tonsils, adenoids, middle ear, nasal sinuses, liver, gall bladder and the colon $[3,4]$.

H. pylori can be detected by a variety of methods; the simplest and least expensive method is serology. Positive serology does not distinguish between active and chronic infection, and is less specific as compared to other methods like histopathology, culture, $H$. pylori faecal antigen or urea breath test $[4,5]$.

The efficacy of $H$. pylori eradication treatment for non-ulcer dyspepsia is controversial, different randomized controlled trails have given conflicting results. Overall, $H$. pylori eradication treatment for non-ulcer dyspepsia had no significant effect on quality of life compared with placebo [6-8]. Further studies comparing between $H$. pylori treatment and eradication for non-ulcer dyspepsia showed improvement of dyspeptic symptoms after treatment or eradication with little differences between them [9].

Observational studies have proposed a protective role of $H$. pylori against the development of gastro-oesophageal reflux disease, and suggested that $H$. pylori eradication treatment may increase the incidence of reflux symptoms. It was observed that the prevalence of $H$. pylori has been decreasing in developed countries, while the prevalence of gastro-oesophageal reflux disease and oesophageal adenocarcinoma have been increasing [10-12]. The appropriate length of $H$. pylori treatment remains also controversial and bacterial resistance and treatment failure would add further controversies concerning the feasibility of eradication [13-15]. 


\section{Aim}

Assessment of the potency of a natural purgative measure on $H$. pylori eradication from the colon.

\section{Design and Setting}

Prospective study done in Balghsoon Clinics in Jeddah/Saudi Arabia during Oct. 2011-May 2013.

\section{Patients and Methods}

22 middle-aged patients (33-51 years old) with recurrent colonic troubles and frank dyspeptic symptoms were included in the study without any social or class selection. The following dyspeptic symptoms were considered; upper abdominal pain, hyperacidity, abdominal distension and constipation. 20 of them (90.9\%) were found positive for colonic $H$. pylori strains by using $H$. pylori fecal antigen test. The potent natural senna leaves purge was employed for them, two of them needed revision of the purge after three days in order to undergo diarrhea.

\section{Results}

A total of 19 patients (95\%) turned negative for colonic $H$. pylori strains.

\section{Ethical Considerations}

An informed signed consent was taken from all patients, they were made aware about safety of the natural senna purge and they were free to quit the study whenever they like. All patients were allowed to lead their routine style of life except restriction of outside-home meals. The research proposal was approved and the study followed the rules of the Research Ethics Committee of King Faisal Specialized Hospital and Research Center in Jeddah, Saudi Arabia.

\section{Discussion}

$H$. pylori colonized the stomach since an immemorial time as if $H$. pylori is a natural bacterium living in peace together with the stomach wall harmless to each other. The organism resides and colonizes under the layer of mucus overlying gastric mucosa; colonization rates increase with age that could reach $50 \%$ in an asymptomatic adult over 50 years of age [3].

H. pylori as all natural bacteria in the gut may change behavior with time due to different reasons such as change of food habits or types of food. $H$. pylori could migrate or get forced to migrate to the colon where it could become a poison itself or becomes a source of poison by producing profuse toxic amounts of ammonia. It has been reported in literature that a possible role of autoimmunity induced by extra-gastric H. pylori strains cannot be excluded. Different reports in literature have confirmed the association of cytotoxin-associated gene A (cagA) positive $H$. pylori strains with many medical problems, and emphasized that cagA of $H$. pylori encodes a highly immunogenic and virulence-associated protein; the presence of this virulent gene in the body could affect the clinical outcome in many patients. $H$. pylori in the colon will continue producing ammonia for a reason or no reason, unopposed or buffered by any acidity, leading to accumulation of ammonia in profuse toxic amounts that could lead adverse toxic effects in the body in predisposed disadvantaged population. H. pylori eradication from the colon in this situation should be therefore a necessary attempt $[3,16,17]$.

Migration of $H$. pylori to the colon is a fact that has been reported in literature $[3,18,19]$. Although the eradication regimens efficiently eradiate $H$. pylori from the stomach; [20] it was suggested that the antibiotic violence could have forced the stomach bacterium to migrate to the colon rather than eradicating it from the stomach. This suggestion is supported by the finding that pseudo-membranous toxic colitis and toxic megacolon have developed after eradication of $H$. pylori from the stomach by antibiotic therapy $[21,22]$. Excess ammonia in the colon is toxic and smooth muscle spastic leading to multiple colonic spasms; a colonic re-absorptive error could establish leading to excessive fluid and salt retention in the body with subsequent burden on blood pressure, heart rate and other effects on heart and circulation [16].

Antibiotics are seldom effective against extra-gastric $H$. pylori strains [23]. Existence of $H$. pylori in the colon is typically life-long unless eradicated, [24] and there is no proven way to eradicate it from the colon rather than the senna purge $[16,19,25]$. It is believed that reduction of $H$. pylori colonization below its pathologic level (50\%) is sufficient to protect from complications $[3,19]$. The natural senna leaves extract purge is valuable and is the measure of choice in eradication of colonic $H$. pylori strains; it is effective as it kills and expels most of the colonic $H$. pylori strains (95\% in this study). In this study and previous scientific efforts, addition of three times dilutions of the seena leaves extract to solid culture media was found to be directly lethal to $H$. pylori colonization $[16,25]$.

\section{Conclusion}

The senna leaves purge should be considered a safe and decisive measure for eradication of colonic $H$. pylori strains; if further reassessment is required for its wider practical application, it should be done without delay in order to employ it for control of disease spread related to extra-gastric $H$. pylori strains.

\section{Acknowledgements}

The study appreciates the facilities and time allowed by Balghsoon Clinics in Jeddah/Saudi Arabia. The continuous support offered by Abdul-Aziz Al-Sorayai Investment Company (ASIC) in Jeddah/Saudi Arabia, the scientific and emotional support of $\mathrm{Dr}$ Ahmed S. Balghsoon are extremely valued and appreciated.

\section{References}

1. Strnad M, Presecki V, Babus V, Turek S, Dominis M, et al. (2002) Epidemiology of Helicobacter pylori infection. Lijec Vjesn 124 Suppl 1: 5-9.

2. Asaka M (2003) [Epidemiology of Helicobacter pylori infection in Japan]. Nihon Rinsho 61: 19-24.

3. Farinha P, Gascoyne RD (2005) Helicobacter pylori and MALT lymphoma. Gastroenterology 128: 1579-1605.

4. Testerman TL, Morris J (2014) Beyond the stomach: an updated view of Helicobacter pylori pathogenesis, diagnosis, and treatment. World J Gastroenterol 20: 12781-12808.

5. Taj Y, Essa F, Kazmi SU, Abdullah E (2003) Sensitivity and specificity of various diagnostic tests in the detection of Helicobacter pylori. J Coll Physicians Surg Pak 13: 90-93. 
Citation: Nasrat AM, Nasrat SAM, Nasrat RM, Nasrat MM (2015) The Definitive Eradication of Helicobacter pylori from the Colon. Gen Med (Los Angel) S1: 1000S1-005. doi:10.4172/2327-5146.1000S1-005

Page 3 of 3

6. McColl K, Murray L, El-Omar E, Dickson A, El-Nujumi A, et al. (1998) Symptomatic benefit from eradicating Helicobacter pylori infection in patients with nonulcer dyspepsia. N Engl J Med 339: 1869-1874.

7. Blum AL, Talley NJ, O'Moráin C, van Zanten SV, Labenz J, et al. (1998) Lack of effect of treating Helicobacter pylori infection in patients with nonulcer dyspepsia. Omeprazole plus Clarithromycin and Amoxicillin Effect One Year after Treatment (OCAY) Study Group. N Engl J Med 339: 1875-1881.

8. Talley NJ, Janssens J, Lauritsen K, Rácz I, Bolling-Sternevald E (1999) Eradication of Helicobacter pylori in functional dyspepsia: randomised double blind placebo controlled trial with 12 months' follow up. The Optimal Regimen Cures Helicobacter Induced Dyspepsia (ORCHID) Study Group. BMJ 318: 833-837.

9. Laheij RJ, van Rossum LG, Verbeek AL, Jansen JB (2003) Helicobacter pylori infection treatment of nonulcer dyspepsia: an analysis of metaanalyses. J Clin Gastroenterol 36: 315-320.

10. Issing WJ (2003) [Gastroesophageal reflux -- a common illness?]. Laryngorhinootologie 82: 118-122.

11. Labenz J, Blum AL, Bayerdörffer E, Meining A, Stolte M, et al. (1997) Curing Helicobacter pylori infection in patients with duodenal ulcer may provoke reflux esophagitis. Gastroenterology 112: 1442-1447.

12. Vakil N (2003) Gastroesophageal reflux disease and Helicobacter pylori infection. Rev Gastroenterol Disord 3: 1-7.

13. Ikeda S, Tamamuro T, Hamashima C, Asaka M (2001) Evaluation of the cost-effectiveness of Helicobacter pylori eradication triple therapy vs. conventional therapy for ulcers in Japan. Aliment Pharmacol Ther 15: 1777-1785.

14. Mason J, Axon AT, Forman D, Duffett S, Drummond M, et al. (2002) The cost-effectiveness of population Helicobacter pylori screening and treatment: a Markov model using economic data from a randomized controlled trial. Aliment Pharmacol Ther 16: 559-568.

15. Breuer T, Graham DY (1999) Costs of diagnosis and treatment of Helicobacter pylori infection: when does choosing the treatment regimen based on susceptibility testing become cost effective? Am J Gastroenterol 94: 725-729.

16. Nsarat RM, Nasrat MM, Nasrat AM, et al. (2015) Improvement of idiopatic cardiomyopathy after colon clear. J Cardiol Res Ap 6: 249-254.

17. Pietroiusti A, Diomedi M, Silvestrini M, Cupini LM, Luzzi I, et al. (2002) Cytotoxin-associated gene-A--positive Helicobacter pylori strains are associated with atherosclerotic stroke. Circulation 106: 580-584.

18. Matsuo S, Mizuta Y, Hayashi T, Susumu S, Tsutsumi R, et al. (2006) Mucosa-associated lymphoid tissue lymphoma of the transverse colon: a case report. World J Gastroenterol 12: 5573-5576.

19. Nasrat AM (2009) The world misconception and misbehavior towards Helicobacter pylori is leading to major spread of illness. The 7th AntiAging Medicine World Congress, Monte-Carlo, Monaco

20. Ge Z (2002) Potential of fumarate reductase as a novel therapeutic target in Helicobacter pylori infection. Expert Opin Ther Targets 6: 135-146.

21. Kubo N, Kochi S, Ariyama I, Murata M, Furusyo N, et al. (2006) [Pseudomembranous colitis after Helicobacter pylori eradication therapy]. Kansenshogaku Zasshi 80: 51-55.

22. Schweigart U, Franck H, Schepp W, Lehn N, Becker K, et al. (1997) [Toxic megacolon after Helicobacter pylori eradication therapy]. Internist (Berl) 38: 352-354.

23. Grünberger B, Wöhrer S, Streubel B, Formanek M, Petkov V, et al. (2006) Antibiotic treatment is not effective in patients infected with Helicobacter pylori suffering from extragastric MALT lymphoma. J Clin Oncol 24: 1370-1375.

24. Asaka M (2003) [Epidemiology of Helicobacter pylori infection in Japan]. Nihon Rinsho 61: 19-24.

25. Nasrat SAM, Nasrat AM (2015) An alternative approach for the rising challenge of hypertensive illness via Helicobacter pylori eradication. J Cardiol Res 6: 221-225.
This article was originally published in a special issue, entitled: "Helicobacter Pylori impact on Human Health", Edited by Hulya Aksoy, Department of Biochemistry, School of Medicine, Atatürk University, Erzurum, TURKEY 